Revue bibliographique pour le domaine irano-aryen

\title{
A Feast in the Mirror, (Stories by Contemporary Iranian Women). Boulder, Colorado, Lynne Rienner, 2000, 235 p.
}

\section{Christophe Balaÿ}

\section{(2) OpenEdition}

1 Journals

Édition électronique

URL : http://journals.openedition.org/abstractairanica/35882

DOI : 10.4000/abstractairanica.35882

ISSN : 1961-960X

Éditeur :

CNRS (UMR 7528 Mondes iraniens et indiens), Éditions de l'IFRI

\section{Édition imprimée}

Date de publication : 15 mai 2002

ISSN : 0240-8910

Référence électronique

Christophe Balaÿ, «A Feast in the Mirror, (Stories by Contemporary Iranian Women). Boulder,

Colorado, Lynne Rienner, 2000, 235 p. », Abstracta Iranica [En ligne], Volume 23 | 2002, document 316, mis en ligne le 08 février 2010, consulté le 25 septembre 2020. URL : http://journals.openedition.org/ abstractairanica/35882 ; DOI : https://doi.org/10.4000/abstractairanica.35882

Ce document a été généré automatiquement le 25 septembre 2020.

Tous droits réservés 


\title{
A Feast in the Mirror, (Stories by Contemporary Iranian Women). Boulder, Colorado, Lynne Rienner, 2000, 235 p.
}

\author{
Christophe Balaÿ
}

1 L'écriture des femmes iraniennes est un des événements majeurs de la littérature persane contemporaine post-révolutionnaire. C'est aussi un phénomène social de première importance. Le nombre de femmes ayant choisi d'écrire après 1978 et la qualité de leur écriture transforment profondément le paysage littéraire. On compte déjà plusieurs anthologies de nouvelles écrites par des femmes en persan et en anglais (grâce à la forte présence de la communauté iranienne aux USA). On attend la même chose en langue française. Les 21 nouvelles traduites ici sont classées, sur un mode poétique, sur trois lignes thématiques intitulées d'après une strophe du célèbre poème de Forūg FarroHzād, Une autre naissance :

2 Voyage (du corps) sur la ligne du temps

3 Impression de ligne barrée du temps

4 (Corps) conscient de l'image

5 (Qui revient de la fête du miroir.) Sur ces trois lignes qu'on franchit pour interroger le sens caché de la vie, qu'on suit pour analyser les réalités socio-politiques, ou qu'on décrit très traditionnellement, les femmes font entendre une symphonie de voix concertantes d'une exceptionnelle richesse humaine. 
INDEX

Thèmes : 11.1.2. Littérature persane moderne

\section{AUTEURS}

CHRISTOPHE BALAY

IFRI - Téhéran 